\title{
RESPON PETANI TERHADAP PENERAPAN \\ USAHATANI JAGUNG HIBRIDA (Zea Mays spp.) POLA TUMPANGSARI
}

(Studi Kasus di Desa Sagalaherang Kecamatan Panawangan Kabupaten Ciamis)

\author{
Oleh : \\ Yuli Nurmayanti ${ }^{1}$, Dini Rochdiani ${ }^{2}$, Cecep Pardani ${ }^{3}$ \\ ${ }^{13}$ Fakultas Pertanian Universitas Galuh \\ ${ }^{2}$ Fakultas Pertanian Universitas Padjadjaran
}

\begin{abstract}
Abstrak
Penelitian ini dilakukan dengan tujuan untuk mengetahui: (1) Respon petani terhadap penerapan usahatani jagung hibrida Bisi 2 pola tumpangsari di Desa Sagalaherang Kecamatan Panawangan Kabupaten Ciamis, dan (2) Berbagai kendala yang dihadapi petani dalam penerapan usahatani jagung hibrida Bisi 2 pola tumpangsari di Desa Sagalaherang.

Jenis Penelitian yang digunakan adalah studi kasus di Desa Sagalaherang Kecamatan Panawangan Kabupaten Ciamis. Sampel responden penelitian adalah 35 petani dari 139 petani jagung hibrida Bisi 2 di Desa Sagalaherang dengan menggunakan metode acak sederhana.

Hasil penelitian menunjukkan bahwa:

1) Tingkat respon petani terhadap penerapan usahatani jagung hibrida Bisi 2 pola tumpangsari di Desa Sagalaherang, secara umum sebagian besar petani responden termasuk ke dalam kategori tinggi dengan rata-rata skor 63,57. Untuk tingkat pengetahuan responden termasuk kategori tinggi dengan rata-rata skor 20,11, sikap responden termasuk dalam kategori tinggi dengan rata-rata skor 21,81, dan keterampilan termasuk dalam kategori tinggi dengan rata-rata skor 21,6.

2) Beberapa kendala yang dihadapi oleh petani dalam penerapan usahatani jagung hibrida Bisi 2 antara lain: (a) Kurangnya bantuan modal dari pemerintah, (b) Kurangnya pengetahuan petani tentang teknologi pertanian, (c) Kurangnya pengendalian hama dan penyakit, (d) Adanya perebutan unsur hara dan sinar matahari pada tanaman, (e) Sulitnya akses jalan dan trasportasi saat pengangkutan hasil panen, serta letak kebun yang jauh dari pemukiman.
\end{abstract}

Kata Kunci: Respon Petani, Usahatani Jagung Hibrida Bisi 2, Tumpangsari

\section{PENDAHULUAN \\ Latar Belakang}

Jagung (Zea mays L.) merupakan salah satu tanaman pangan penting selain gandum dan padi. Kebutuhan jagung saat ini mengalami peningkatan, dapat dilihat dari segi produksi, dimana permintaan pasar domestik ataupun internasional sangat besar untuk kebutuhan pangan dan pakan (Supratomo, 2006).

Kemajuan dalam peningkatan produktivitas serta kualitas hanya bisa diraih dengan penerapan teknologi. Teknologi budidaya adalah untuk meningkatkan produksi tanaman meliputi: pemilihan varietas (Benih), pengolahan tanah dan perbaikan kesuburan, penanaman, pemeliharaan, pengelolaan organisme pengganggu tanaman dan panen (Musa, 2011).

Kabupaten Ciamis merupakan salah satu daerah yang memiliki potensi jagung yang cukup besar. Kecamatan Panawangan merupakan salah satu kecamatan di Kabupaten Ciamis yang memproduksi jagung varietas yang dibudidayakan adalah varietas jagung hibrida Bisi 2. Desa yang memiliki potensi jagung hibrida Bisi 2 paling besar di Kecamatan Panawangan adalah Desa
Sagalaherang.

Sistem tanam yang diterapkan oleh petani di Kecamatan Panawangan termasuk Desa Sagalaherang dalam usahatani jagung hibrida adalah pola tumpangsari (BP3K Kecamatan Panawangan). Pola tumpangsari merupakan pola penanaman campuran (polyculture) dengan menanam lebih dari satu jenis tanaman pada suatu hamparan lahan dalam periode waktu tanam yang sama (Anwar, 2012).

Lemahnya permodalan petani di Kecamatan Panawangan merupakan salah satu kendala dalam peningkatan produktivitas tanaman jagung hibrida. Menurut Nurindah, (2006) pola tumpangsari merupakan salah satu teknik pola tanam yang dari segi usahatani mampu memberikan keuntungan ekonomi dan mengurangi resiko kegagalan panen sehingga modal petani dapat terjaga dan lebih meningkat.

Penerapan pola tumpangsari dalam usahatani jagung hibrida yang dilakukan menimbulkan respon petani di Desa Sagalaherang. Menurut Anggoro (2004) respon petani adalah 
tanggapan atau reaksi yang yang dilakukan petani terhadap suatu hal yang baru. Respon petani juga dapat diartikan sebagai suatu perubahan sikap petani yang diakibatkan adanya rangsangan (stimulus) dari luar dan dari dalam diri petani dalam wujud melaksanakan program, memperluas areal pertanian, memperbanyak hasil produksi dan mengumpulkan serta menyebarluaskan informasi teknologi.

\section{Identifikasi Masalah}

Berdasarkan uraian pada latar belakang maka masalah yang dapat diidentifikasi dalam penelitian ini adalah sebagai berikut:

1. Bagaimana respon petani terhadap penerapan usahatani jagung hibrida Bisi 2 pola tumpangsari di Desa Sagalaherang Kecamatan Panawangan Kabupaten Ciamis ?

2. Bagaimana kendala-kendala yang dihadapi petani dalam penerapan usahatani jagung hibrida Bisi 2 pola tumpangsari di Desa Sagalaherang Kecamatan Panawangan Kabupaten Ciamis ?

\section{Tujuan Penelitian}

Penelitian ini bertujuan untuk mengetahui:

1. Respon petani terhadap penerapan usahatani jagung hibrida Bisi 2 pola tumpangsari di Desa Sagalaherang Kecamatan Panawangan Kabupaten Ciamis.

2. Kendala-kendala yang dihadapi petani dalam penerapan usahatani jagung hibrida Bisi 2 pola tumpangsari di Desa Sagalaherang Kecamatan Panawangan Kabupaten Ciamis.

\section{TINJAUAN PUSTAKA}

\section{Pengertian Respon}

Respon adalah suatu reaksi atau jawaban yang bergantung pada stimulus atau merupakan hasil stimulus tersebut. Individu serta sebagai pengendali antara stimulus dan respon sehingga yang menentukan bentuk respon individu terhadap stimulus adalah stimulus dan faktor individu itu sendiri (Azwar, 2008).

Untuk mengetahui respon petani terhadap suatu kegiatan dapat diketahui melalui proses antara lain:

\section{a. Pengetahuan}

Pengetahuan adalah suatu proses dengan menggunakan pancaindra yang dilakukan seseorang terhadap objek tertentu yang dapat menghasilkan pengetahuan dan keterampilan (Hidayat, 2007).

\section{b. Sikap}

Sikap merupakan kesiapan merespon yang sifatnya positif atau negatif terhadap objek atau situasi secara konsisten (Ahmadi, 2007).

\section{c. Keterampilan}

Keterampilan adalah kegiatan yang berhubungan dengan urat syaraf yang meliputi semua tugas-tugas kecakapan, sikap, nilai dan kemengertian yang semuanya dipertimbangkan sebagai sesuatu yang penting untuk menjaga keberhasilannya dalam menyelesaikan tugas (Muhbin Syah, 2006).

Jagung

Tanaman jagung yang dalam bahasa ilmiahnya disebut Zeea Mays L., adalah salah satu jenis tanaman biji-bijian yang menurut sejarahnya berasal dari Amerika. Baru sekitar abad ke-16 tanaman jagung ini oleh orang Protugis dibawa ke Pakistan, Tiongkok dan daerah-daerah lainnya di Asia termasuk Indonesia (Wirawan dan Wahab, 2007).

\section{Pola Tanam Tumpangsari}

Tumpangsari merupakan suatu usaha menanam beberapa jenis tanaman pada lahan dalam waktu yang sama, yang di atur sedemikian rupa dalam baris-baris tanaman. Penanaman dengan cara ini bisa dilakukan pada dua atau lebih jenis tanaman yang relatif seumur, misalnya jagung dan kacang tanah atau bisa juga pada jenis tanaman yang umurnya berbeda-beda (Hendroatmodjo, 2009).

\section{METODE PENELITIAN}

\section{Jenis penelitian}

Jenis penelitian yang digunakan adalah studi kasus pada petani jagung hibrida Bisi 2 di Desa Sagalaherang Kecamatan Panawangan Kabupaten Ciamis. Menurut Walgito (2010) studi kasus merupakan suatu metode untuk menyelidiki atau mempelajari suatu kejadian mengenai suatu subjek penelitian.

\section{Teknik Pengumpulan Data}

Data yang dikumpulkan dalam penelitian ini meliputi data primer dan data Sekunder. Data primer dan data sekunder yang terkumpul selanjutnya diolah dan dianalisis secara deskriptif.

\section{Teknik Penarikan Sampel}

Unit analisis pada penelitian ini adalah petani jagung hibrida Bisi 2 di Desa Sagalaherang Kecamatan Panawangan Kabupaten Ciamis. Penarikan sampel responden untuk petani jagung hibrida Bisi 2 dilakukan dengan menggunakan metode acak sederhana (Simple Random Sampling). Jumlah sampel ditentukan sebesar 25 persen dari 139 petani jagung hibrida Bisi 2 di Desa Sagalaherang yaitu sebanyak 35 sampel responden.

\section{Rancangan Analisis Data}

Respon petani terhadap penerapan usahatani jagung hibrida pola tumpangsari di Desa Sagalaherang di bagi dalam tiga kategori. Untuk menentukan panjangnya kelas interval masingmasing kategori dilakukan penghitungan sebagai berikut (Sudjana, 2003): 


$$
\begin{gathered}
\text { panjang kelas interval }=\frac{\text { Rentang }}{\text { Jumlah kelas }} \\
=\frac{\text { Nilai maksimal }- \text { nilai minimal }}{\text { Kategori }} \\
=\frac{72-24}{3}=16
\end{gathered}
$$

Keterangan:

Nilai Maksimal : Nilai tertinggi dari masingmasing variabel dan indikatornya

Nilai Minimal : Nilai terendah dari masingmasing variabel dan indikatornya interval masing-masing kategori sebagai berikut:
(1) Tingkat respon rendah
$: 24 \leq \mathrm{Q}<40$
(2) Tingkat respon sedang
$: 40 \leq \mathrm{Q}<56$
(3) Tingkat respon tinggi
: $56 \leq \mathrm{Q} \leq 72$

Keterangan:

$\mathrm{Q}=$ Nilai yang di capai

Penentuan sekor untuk mengukur respon petani terhadap penerapan usahatani jagung hibrida pola tumpangsari dapat dilihat pada Tabel 1.

Tabel 1.Tingkat Respon Petani Terhadap Penerapan Usahatani Jagung Hibrida Pola Tumpangsari

\begin{tabular}{|c|l|c|}
\hline No & \multicolumn{1}{|c|}{ Indikator } & Kisaran Skor \\
\hline 1 & Pengetahuan & $8-24$ \\
2 & Sikap & $8-24$ \\
3 & Keterampilan & $8-24$ \\
\hline & Jumlah & $24-72$ \\
\hline
\end{tabular}

Sedangkan untuk mengetahui respon terhadap masing-masing indikator, dengan menggunakan rumus yang sama. Maka dapat diketahui tingkat responnya dari masing-masing indikator sebagaimana dapat dilihat pada Tabel 2.

Tabel 2. Kategori Tingkat Respon Petani Untuk Masing-masing Indikator
Dari rumusan tersebut maka dapat ditentukan

Tempat dan Waktu Penalitian

Penelitian dilaksanakan di Desa Sagalahrang Kecamatan Panawangan Kabupaten Ciamis. Waktu pelaksanaan penelitian yaitu pada bulan Maret sampai Juni 2016.

\section{HASIL DAN PEMBAHASAN}

A. Identitas Responden

Indikator yang digunakan identitas responden meliputi beberapa aspek antara lain umur, tingkat pendidikan, pengalaman berusaha, luas lahan usahatani jagung hibrida Bisi 2 pola tumpangsari.

\section{Umur Responden}

Berdasarkan hasil penelitian diketahui bahwa usia responden berkisar antara 33 tahun sampai 64 tahun. Untuk lebih jelasnya dapat dilihat pada Tabel 3.

Tabel 3. Keadaan Responden Berdasarkan Keadaan Umur

\begin{tabular}{|c|c|c|c|}
\hline No & $\begin{array}{c}\text { Usia } \\
\text { (Tahun) }\end{array}$ & $\begin{array}{c}\text { Jumlah } \\
\text { (Orang) }\end{array}$ & $\begin{array}{c}\text { Persentase } \\
(\%)\end{array}$ \\
\hline 1 & $33-43$ & 7 & 20,00 \\
2 & $44-54$ & 18 & 51,43 \\
3 & $55-64$ & 10 & 28,57 \\
& & 35 & 100,00 \\
\hline \multicolumn{2}{|c|}{ Total } & 35
\end{tabular}

Tabel 3 menunjukkan bahwa seluruh responden termasuk kedalam usia produktif, karena umur responden berkisar antara 33-64 tahun.

2. Tingkat Pendidikan

Keadaan responden berdasarkan tingkat pendidikan dapat dilihat pada Tabel 4.

Tabel 4. Keadaan Responden Berdasarkan Tingkat Pendidikan

\begin{tabular}{|c|c|c|c|}
\hline No & $\begin{array}{c}\text { Tingkat } \\
\text { Pendidikan }\end{array}$ & $\begin{array}{c}\text { Jumlah } \\
\text { (orang) }\end{array}$ & $\begin{array}{c}\text { Presentase } \\
(\%)\end{array}$ \\
\hline 1 & SD & 31 & 88,57 \\
2 & SMP & 2 & 5,71 \\
3 & SMA & 1 & 2,86 \\
4 & D1 & 1 & 2,86 \\
& & 35 & 100,00 \\
\hline
\end{tabular}

Keteramablen 4 menunjukkan, bahwa tingkat

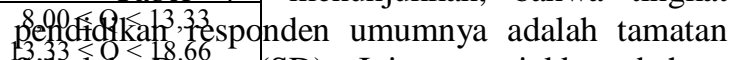
Sejoła $\leq 2$,qsar (SD), Ini menunjukkan bahwa kebanyakan pendidikan responden masih tergolong rendah.

Sedangkan untuk mengetahui berbagai kendala yang dihadapi petani dalam mengembangkan usahatani jagung hibrida pola tumpangsari di Desa Sagalaherang dilakukan analisis secara deskriptif.

\section{Pengalaman Berusahatani Jagung Hibrida}

Pola Tumpangsari

Berdasarkan hasil penelitian, pengalaman responden dalam melaksanakan usahatani jagung 
hibrida Bisi 2 pola tumpangsari dapat dilihat pada Tabel 5.

Tabel 5. Keadaan Responden berdasarkan Pengalaman Berusahatani Jagung Hibrida Bisi 2 Pola Tumpangsari

\begin{tabular}{|c|c|c|c|}
\hline No & $\begin{array}{c}\text { Pengalaman } \\
\text { Berusahatani } \\
\text { (Tahun) }\end{array}$ & $\begin{array}{c}\text { Jumlah } \\
\text { (Orang) }\end{array}$ & $\begin{array}{c}\text { Persentase } \\
(\%)\end{array}$ \\
\hline 1 & $3-5$ & 1 & 2,86 \\
2 & $6-8$ & 5 & 14,28 \\
3 & $9-12$ & 29 & 82,86 \\
\hline \multicolumn{2}{|c|}{ Total } & 35 & 100,00 \\
\hline
\end{tabular}

Tabel 5 menunjukkan bahwa pengalaman berusahatani responden dalam menerapkan usahatani jagung hibrida Bisi 2 pola tumpangsari yaitu 3 sampai 5 tahun hanya 1 orang $(2,86$ persen), 6 sampai 8 tahun sebanyak 5 orang $(14,28$ persen), 9 sampai 12 tahun sebamyak 29 orang (82,86 persen).

4. Luas Lahan Usahatani Jagung Hibrida Pola Tumpangsari

Untuk lebih jelasnya mengenai luas lahan responden yang ditanami jagung hibrida Bisi 2 pola tumpangsaridapat dilihat pada Tabel 6 .

Tabel 6. Keadaan Responden Berdasarkan Luas Lahan Usahatani Jagung Hibrida Bisi 2 Pola Tumpangsari

\begin{tabular}{|c|c|c|c|}
\hline No & $\begin{array}{c}\text { Luas Lahan } \\
(\mathrm{Ha})\end{array}$ & $\begin{array}{c}\text { Jumlah } \\
(\text { Orang) }\end{array}$ & $\begin{array}{c}\text { Persentase } \\
(\%)\end{array}$ \\
\hline 1 & $<0,25$ & 20 & 57,14 \\
2 & $0,25-0,50$ & 10 & 28.58 \\
3 & $>0,50$ & 5 & 14,28 \\
& Total & 35 & 100,00 \\
\hline
\end{tabular}

Berdasarkan tabel dapat diketahui bahwa sebagian besar responden memiliki luas lahan yang sempit untuk menanam jagung.

Kajian Respon Petani Terhadap Usahatani Jagung Hibrida Bisi 2 Pola Tumpangsari

Respon petani terhadap penerapan usahatani jagung hibrida Bisi 2 pola tumpngsari dinyatakan berdasarkan nilai skor. kriteria yang digunakan untuk mengetahui respon petani jagung di Desa Sagalaherang Kecamatan Panawangan dalam penerapan usahatani jagung hibrida Bisi 2 pola tumpangsari. Untuk kriteria tersebut dibagi dalam tiga kategori sebagaimana diuraikan dalam metode penelitian.

\section{Tingkat Pengetahuan Responden Terhadap Usahatani Jagung Hibrida Bisi 2 Pola Tumpangsari}

Berdasarkan hasil penelitian diketahui, bahwa tingkat pengetahuan responden terhadap kegiatan usahatani jagung hibrida pola tumpangsari termasuk ke dalam kategori tinggi, sebagaimana dapat dilihat pada Tabel 7.

Tabel 7. Tingkat Pengetahuan Responden Terhadap Penerapan Usahatani Jagung Hibrida Bisi 2 Pola Tumpangsari

\begin{tabular}{|c|c|c|c|c|}
\hline $\begin{array}{l}\mathrm{N} \\
\mathrm{o}\end{array}$ & $\begin{array}{c}\text { Kategori } \\
\text { Tingkat } \\
\text { Responden }\end{array}$ & $\begin{array}{c}\text { Nilai } \\
\text { (Kisaran Skor) }\end{array}$ & $\begin{array}{c}\text { Jumlah } \\
\text { Petani } \\
\text { Orang }\end{array}$ & $\begin{array}{c}\text { Persen } \\
\text { tase } \\
(\%) \\
\end{array}$ \\
\hline 1 & Rendah & $8,00 \leq \mathrm{Q}<13,33$ & 1 & 2,86 \\
\hline 2 & Sedang & $13,33 \leq \mathrm{Q}<18,66$ & 8 & 22,86 \\
\hline 3 & Tinggi & $18,66 \leq \mathrm{Q} \leq 24,00$ & 26 & 74,28 \\
\hline \multicolumn{3}{|c|}{ Jumlah } & 35 & 100,00 \\
\hline
\end{tabular}

Berdasarkan Tabel 7 diketahui bahwa sebagian besar sampel petani responden yaitu sebanyak 26 orang atau 74,28 persen, tingkat pengetahuannya terhadap usahatani jagung hibrida Bisi 2 pola tumpangsari termasuk katagori tinggi. Hal tersebut menunjukkan bahwa petani jagung di Desa Sagalaherang Kecamatan Panawangan secara umum telah menyadari manfaat dari penerapan usahatani jagung hibrida Bisi 2 pola tumpangsari guna memberikan keuntungan bagi petani terutama dalam meningkatkan pendapatan petani. Dari hasil penelitian untuk tingkat pengetahuan terdapat data dari skoring maksimal 24, didapat rata-rata sekor dilapangan hasil penelitian 20,11 termasuk dalam kategori tinggi.

2.Sikap Responden Terhadap Usahatani Jagung Hibrida Bisi 2 Pola Tumpangsari

Berdasarkan hasil penelitian diketahui, bahwa respon petani terhadap penerapan usahatani jagung hibrida Bisi 2 pola tumpangsari termasuk kedalam kategori tinggi, sebagai mana dapat dilihat pada Tabel 8.

Tabel 8. Sikap Responden Terhadap Penerapan Usahatani Jagung Hibrida Bisi 2 Pola Tumpangsari

\begin{tabular}{|c|c|c|c|c|}
\hline $\begin{array}{l}\mathrm{N} \\
\mathrm{O}\end{array}$ & $\begin{array}{c}\text { Kategori } \\
\text { Tingkat } \\
\text { Responden }\end{array}$ & $\begin{array}{c}\text { Nilai } \\
\text { (Kisaran Skor) }\end{array}$ & $\begin{array}{c}\text { Jumlah } \\
\text { Petani } \\
\text { Orang }\end{array}$ & $\begin{array}{c}\text { Persen } \\
\text { tase } \\
(\%)\end{array}$ \\
\hline 1 & Rendah & $8,00 \leq \mathrm{Q}<13,33$ & 0 & 0 \\
\hline 2 & Sedang & $13,33 \leq \mathrm{Q}<18,66$ & 3 & 8,58 \\
\hline 3 & Tinggi & $18,66 \leq \mathrm{Q} \leq 24,00$ & 32 & 91,42 \\
\hline \multicolumn{3}{|c|}{ Jumlah } & 35 & 100 \\
\hline
\end{tabular}

Berdasarkan Tabel 8 diketahui bahwa sebagian besar sampel petani responden yaitu sebanyak 32 orang atau 91,42 persen. Sikapnya terhadap 
penerapan usahatani jagung hibrida Bisi 2 pola tumpangsari termasuk kategori tinggi. Hal tersebut disebabkan adanya beberapa faktor dalam diri petani diantaranya: kegiatan usahatani jagung hibrida Bisi 2 dilaksanakan petani atas dasar dari keinginan diri petani sendiri, kebiasaan melaksanakan usahatani jagung pola tumpangsari sebagai tambahan pendapatan petani, kondisi lingkungan yaitu lahan yang cukup untuk menanam jagung pola tumpangsari, ditambah varietas jagung hibrida Bisi 2 yang pernah diberikan oleh pemerintah dapat meningkatkan hasil produksi dari pada varietas lokal, penerapan usahatani jagung hibrida Bisi 2 juga dapat dilakukan dengan mudah oleh petani. Dari hasil penelitian untuk kategori sikap tedapat data dari skor maksimal 24, didapat rata-rata skor dilapangan hasil penelitian responden 21, 81 termasuk dalam kategori tinggi.

3. Tingkat Keterampilan Responden Pada Penerapan Usahatani Jagung Hibrida Bisi 2 Pola Tumpangsari

Keterampilan adalah bagaimana petani responden menerapkan cara-cara berusahatani jagung hibrida Bisi 2 pola tumpangsari yang telah disampaikan oleh pemerinta atau penyuluh. Keterampilan responden menunjukkan seberapa besar responden mengikuti petunjuk yang telah diberikan. Berdasarkan hasil penelitian diketahui, bahwa tingkat keterampilan responden pada kegiatan usahatani jagung hibrida Bisi 2 pola tumpangsari termasuk kedalam kategori tinggi sebagai mana dapat dilihat pada Tabel 9.

Tabel 9. Tingkat Keterampilan Petani Pada Kegiatan Usahatani Jagung Hibrida Bisi2 Pola Tumpangsari

\begin{tabular}{|c|c|c|c|c|}
\hline $\begin{array}{l}\mathrm{N} \\
\mathrm{o}\end{array}$ & $\begin{array}{c}\text { Kategori } \\
\text { Tingkat } \\
\text { Responden }\end{array}$ & $\begin{array}{c}\text { Nilai } \\
\text { (Kisaran Skor) }\end{array}$ & $\begin{array}{c}\text { Jumlah } \\
\text { Petani } \\
\text { Orang }\end{array}$ & $\begin{array}{c}\text { Persen } \\
\text { tase } \\
(\%)\end{array}$ \\
\hline 1 & Rendah & $8,00 \leq \mathrm{Q}<13,33$ & 0 & 0,00 \\
\hline 2 & Sedang & $13,33 \leq Q<18,66$ & 1 & 2,86 \\
\hline 3 & Tinggi & $18,66 \leq \mathrm{Q} \leq 24,00$ & 34 & 97,14 \\
\hline \multicolumn{3}{|c|}{ Jumlah } & 35 & 100,00 \\
\hline
\end{tabular}

Berdasarkan Tabel 9 diketahui bahwa sebagian petani sampel responden yaitu sebanyak 34 orang atau 97,14 persen, tingkat keterampilannya dalam kegiatan usahatani jagung Hibrida Bisi 2 termasuk kategori tinggi. Dari hasil penelitian pada Lampira 5, untuk keterampilan terdapat data dari skor 24, didapat rata-rata skor dilapangan hasil penelitian responden 21,6 termasuk dalam kategori tinggi. Hal tersebut menunjukkan bahwa petani jagung di Desa Sagalaherang Kecamatan Panawangan secara umum telah terampil dalam melaksanakan usahatani jagung hibrida Bisi 2 pola tumpangsari.

\section{Tingkat Respon Petani Terhadap Penerapan Usahatani jagung Hibrida Bisi 2 Pola tumpangsari}

Berdasarkan hasil penghitungan diketahui, bahwa tingkat respon petani terhadap penerapan usahatani jagung hibrida Bisi 2 pola tumpangsari oleh petani sampel responden dapat dilihat pada Tabel 10.

\section{Tabel 10. Tingkat Respon Petani Terhadap Penerapan Usahatani Jagung Hibrida Bisi 2 Pola Tumpangsari}

\begin{tabular}{|c|c|c|c|c|}
\hline $\begin{array}{l}\mathrm{N} \\
\mathrm{O}\end{array}$ & $\begin{array}{c}\text { Kategori } \\
\text { Tingkat } \\
\text { Responden }\end{array}$ & $\begin{array}{c}\text { Nilai } \\
\text { (Kisaran } \\
\text { Skor) }\end{array}$ & $\begin{array}{c}\text { Jumlah } \\
\text { Petani } \\
\text { (Orang) }\end{array}$ & $\begin{array}{c}\text { Persen } \\
\text { tase } \\
(\%) \\
\end{array}$ \\
\hline 1 & Rendah & $24 \leq \mathrm{Q}<40$ & - & - \\
\hline 2 & Sedang & $40 \leq \mathrm{Q}<56$ & 1 & 2,86 \\
\hline 3 & Tinggi & $56 \leq \mathrm{Q} \leq 72$ & 34 & 97,14 \\
\hline & \multicolumn{2}{|c|}{ Jumlah } & 35 & 100,00 \\
\hline
\end{tabular}

Berdasarkan Tabel 10 diketahui bahwa 34 orang atau 97,14 persen petani sampel responden, mempunyai tingkat respon yang tinggi terhadap penerapan usahatani jagung hibrida bisi 2 pola tumpangsari. Hal tersebut menunjukkan bahwa petani jagung di desa sagalaherang kecamatan panawangan secara umum telah menyadari pentingnya penerapan usahatani jagung hibrida bisi 2 pola tumpangsari untuk memenuhi kebutuhan keluarga, meningkatkan pendapatan petani, membantu mengurangi kegagalan panen, menekan biaya tenaga kerja, hasil produksi dapat meningkat. Untuk memenuhi hal tersebut diperlukan teknologi budidaya yang benar agar diperoleh hasil yang optimal.

Penerapan usahatani jagung hibrida Bisi 2 pola tumpangsari sudah sepenuhnya diadopsi oleh para petani karena tingkat pengetahuan, sikap, keterampilan termasuk kategori tinggi dengan ratarata skor 63,57 .

Kendala yang Dihadapi Petani dalam Penerapan Usahatani Jagung Hibrida Bisi 2 Pola Tumpangsari

Secara umum respon petani jagung di Desa Sagalaherang cukup baik, Karena sebagian besar telah mencapai kategori tinggi. Namun demikian masih ada beberapa kendala yang dihadapi petani antara lain:

1. Kurangnya bantuan modal dari pemerintah. Petani sangat mengharapkan adanya bantuan modal dari pemerintah dengan memudahkan simpan pinjam uang bagi petani, agar kegiatan usahatani jagung hibrida Bisi 2 pola tumpangsari dapat lebih memajukan dan meningkatkan pendapatan petani.

2. Kurangnya mendapatkan pengetahuan oleh petani yang tinggi tentang teknologi pertanian, 
contohnya pengetahuan waktu yang tepat untuk menanam agar saat panen tiba harga jagung cukup baik.

3. Kurangnya pengendalian hama dan penyakit karena tidak memiliki alat penyemprotan karena tidak adanya bantuan pemerintah dalam menyediakan peminjaman alat-alat pertanian, ditambah harga obat yang mahal.

4. Adanya perebutan unsur hara dan sinar matahari sehingga apabila tanaman jagung bagus produksi kacang tanah kurang bagus. hal ini dikarenakan kurangnya pemupukan yang benar-benar optimal dikarenakan harga pupuk yang mahal.

5. Sulitnya akses jalan dan transportasi saat pengangkutan hasil panen, serta letak kebun yang jauh dari pemukiman, sehingga menimbulkan tambahan biaya pengangkutan.

\section{KESIMPULAN DAN SARAN \\ Kesimpulan}

Berdasarkan hasil dan pembahasan maka dapat diambil kesimpulan sebagai berikut:

1. Secara umum respon petani terhadap penerapan usahatani jagung hibrida Bisi 2 pola tumpangsari termasuk kedalam kategori tinggi, karena sebagian besar petani responden yaitu sebanyak 34 orang atau 97,14 persen, mempunyai tingkat respon yang tinggi pada penerapan usahatani jagung hibrida bisi 2 pola tumpangsari dengan rata-rata skor 63,57. Pada tingkat pengetahuan responden sebagian besar petani responden yaitu sebanyak 26 orang atau 74,28 persen termasuk kategori tinggi dengan rata-rata skor 20,11. Pada tingkat sikap sebanyak 32 orang atau 91,42 persen termasuk kategori tinggi dengan rata-rata skor 21,81. Pada tingkat keterampilan responden sebanyak 34 orang atau 97,14 persen termasuk kategori tinggi dengan rata-rata skor 21,6.

2. Beberapa kendala yang dihadapi petani pada penerapan usahatani jagung hibrida pola tumpangsari diantaranya:

a. Kurangnya bantuan modal dari pemerintah

b. Kurangnya pengetahuan petani tentang teknologi pertanian

c. Tidak adanya alat untuk pengendalian hama dan penyakit serta obat pembasmi hama dan penyakit mahal

d. Adanya perebutan unsur hara dan sinar matahari pada tanaman dikarenakan kurangnya pemberian pupuk yang cukup karena harga pupuk yang mahal

e. Sulitnya akses jalan dan transportasi saat pengangkutan hasil pertanian, serta letak kebun yang jauh dari pemukiman menimbulkan tambahan biaya pengangkutan.

\section{Saran}

Berdasarkan hasil kesimpulan maka peneliti menyarankan sebagai berikut:

1. Petani harus aktif mengikuti organisasi pertanian (kelompok tani), dengan begitu petani bisa menambah ilmu pengetahuan teknologi pertanian. Serta meskipun tidak ada bantuan dari pemerintah tetapi dengan membentuk organisasi petani bisa membuka sistem pinjam uang untuk membantu modal petani.

2. Pihak pemerintah sebaiknya memberikan perhatian bagi petani khususnya petani jagung, dengan cara memudahkan sistem pengkreditan bagi petani, pemberian alat pertanian untuk dapat digunakan oleh petani, pemberian pupuk bersubsidi, membangun jalan agar proses pengangkutan tidak sulit.

\section{DAFTAR PUSTAKA}

Anggoro, N. 2004. Respon Petani Terhadap Pogram Konservasi Tanah di Kabupaten Kelaten. Universitas Gajah Mada. Yogyakarta

Anwar. 2012. Sitem Pertanian Tumpangsari. Malang.

BP3K Kecamatan Panawangan. Realisasi Luas Panen, Produksi dan Produktivitas Tanaman Jagung. 2015.

Dinas Pertanian Tanaman Pangan Kabupaten Ciamis. 2015. Realisasi Tanaman Jagung 2015. Ciamis.

Hendroatmadjo. 2009. Teknik Budidaya Tanaman Monokultur dan Tumpangsari. Universitas Lampung

Hidayat. 2007. Metodologi Penelitian Kesehatan. Bineka Cipta. Jakarta

Hilmi, S dan Humsona, R. 2008. Respon Negatif Siswa Terhadap Pemberian Pembelajaran Bahasa Inggris. Universitas Sebelas Maret.

Musa, Y. 2011. Manajemen Teknologi Budidaya Jagung. Makalah disampaikan pada : Pelatihan Serealia.

Nurindah. 2006. Pengaruh Tumpangsari Kapas dengan Palawija terhadap Populasi Predator Serangan Hama Kapas. Seri Pengembangan No.7. Malang

Prabowo, A.Y. 2011. Teknis Budidaya. Yogyakarta

Prasetyo. 2007. Metode Penelitian Kuantitatif. Grafibdo. Jakarta

Purwono dan Purnawati, H. 2013. Budidaya 8 Jenis Tanaman Pangan Unggul. Penebar Sadaya. Jakarta

Purwono dan R. Hartono. 2011. Bertanam Jagung Unggul. Penebar Suadaya. Jakarta

Sudjana. 2003. Metode Statistika. Tarsito. Bandung 
Sugiyono. 2007. Metode Penelitian Administrasi. Alfabet. Bandung

Syaiful A.S., A Yassi, N. Rizkiani. 2011. Respon Tumpangsari Tanaman Jagung dan Kacang Hijau Terhadap Sistem Oleh Tanah dan Pemberioan Pupuk Organik. Jurnal Agronomika.

Warsana. 2009. Introduksi Teknologi Tumpangsari Jagung dan Kacang Tanah. BPTP. Jawa Tengah

Yusuf. 2007. Pisikologi Perkembangan Anak dan Remaja. Bandung 